\title{
„Studii și cercetări de onomastică și lexicologie” (sCOL), Year X, No. 1-2, 2017, 334 p.
}

\author{
Daniela Butnaru* \\ "A. Philippide" Institute of Romanian Philology, Str. Th. Codrescu 2, 700481 Iași, Romania
}

Thanks to the efforts of the editorial team coordinated by professor Silvia Pitiriciu from the University of Craiova, SCOL is issued annually, comprising a substantial number of contributions signed by both experienced researchers in the fields of Onomastics and Lexicology and beginner researchers passionate by these fields. The fact that the articles are written in English and French and also published in electronic form [online], along with being listed in international indexation databases renders the information available. The volume published in 2017 is dedicated to Ioana Vintilă-Rădulescu, about whom Dragoș Vlad Topală writes with genuine emotion in the first pages.

Starting from the observation that toponyms derived from group names are extremely numerous, Iustina Burci aims at analyzing, based on the material published in Dictionarului toponimic al României. Muntenia [Romania's Dictionary of Toponymy. Wallachia], the existence of toponymic names originating from group names and formed by derivation with various collective suffixes from the same word (Names of Places with Pair Suffixes, in the Toponymy of Muntenia, p. 19-29). Although the title clearly indicates that the study deals with toponyms formed with pair suffixes, on pages p. 2226 the author introduces pair/triplet group names (which subsequently turned into toponyms) formed from either identical basis or basis that are similar to various 'formative factors' such as: -ani/-eni (starting from the toponym Argeş there resulted the group names argeșani and argeșeni), - ani/-ăști/-ești (from the person name Cioara/Cioară there resulted ciorani, ciorăști, ciorești ${ }^{1}$ ), -ani/-eni/-ești (from the toponym Buda there allegedly resulted budani, budeni and budești), -ești/-oci (from Homocea there resulted homocești and homoci $i^{2}$ ), $-i /-i i$ (from the appellative josean there resulted the group names joseni and josenii $i^{3}$ ), etc. In order to observe the formation of group names with various equivalent formative factors it would have been really interesting for the discussion to focus just on names of places that display two or more formal variations, but imply the same referent, a few examples in this respect being provided on page p. 29. The author claims that the suffix -ești is not used exclusively for the formation of place names starting from anthroponyms and exemplifies with toponyms such as Piscurești, derived from the homonym group name, that was allegedly formed, in turn, from the toponym Piscuri (p. 20), Cuibești, which supposedly derived from the toponym Cuibu (p. 22), Budești, originating from the place name $B u d a$ (p. 23), and so on. In our opinion, it would have been more appropriate to forward evidence extracted from either documents or field investigations that would prove the derivation with the suffix -ești from place names! Quoting from Iorgu Iordan is far from sufficient, since in his work entitled Toponimia românească [Romanian Toponymy] some errors occur for the very reason that the author failed to use information from investigations and collections of documents. A critical approach towards the etymologies listed in the dictionary would have served this study much better. One can exemplify this issue with the toponyms Budani, Budeni and Budești, derived from the homonym names of groups and whose origin is supposed to be the toponym Buda (p. 22-23). The

*Email address:d_butnaru@yahoo.com.

${ }^{1}$-ăști is actually the suffix - ești with a velar $-e-$, consequently it should not be considered separately.

${ }^{2}$ Homoci does not result from the suffixation with -oci, but it represents either a plural form of the anthroponym Homocea, or a graphic form, from 1870, of the toponym Homocea (in the dictionary, both toponyms, Homocea and Homoci, are defined as an estate situated in the village of Cîmpulungeanca, the locality of Mărgăritești in Buzău, the former attested in 1908 and the latter in 1870; we believe in this case we are dealing with two versions of the same name of place).

${ }^{3}$ In this particular case we are presented with the definite and indefinite plural form of the same appellative, thus such a differentiation is not applicable here. 
first volume of Dicţionarului toponimic al Munteniei [The Toponymic Dictionary of Wallachia], indicates that the toponym Budani designates a part of the village of Cărpenis,, the locality of Cepari, Argeș county, while Budeni used to designate a village of the same locality in Argeș, Cepari, merged in 1956 with the village of Cărpeniș (which entitles us to ask whether Budeni is in fact just a version of the name Budani), and Budessti would be the name of a part of the village in the locality of Cepari. From the monograph Comuna Cepari, județul Argeș. Trepte in timp (Pitești, Editura Ordessos, 2008), signed by Ion I. Năstase and Elena I. Stătică, we learn that in the village of Cărpenis there were, at the beginning of the $20^{\text {th }}$ century, several people whose family name was Budan (p. 67), which means that the name of locality Budani comes from the family name $B u d a n^{4}$ in the plural form and not from the toponym Buda. In the neighbouring village, Urluiești, where a road named Budesti can be found, some locals bearing the family name Buda and Budescu are attested in the same period (p. 62, 71 și 72). Therefore, the anthroponymic origin of the toponym Budești is more plausible. One last observation is meant to point to the fact that in the locality of Traian in the county of Brăila there is the village of Urleasca, not Ulmeasca, as is mentioned on p. 20.

The title of the article signed by Dumitru Carabaș from "Ovidius" University of Constanța promises to present Some elements of the Bulgarian influence on Aromanian onomastics (p. 3040). While reading the article we kept wondering what the author means by "elements of Bulgarian influence". This is because for the anthroponyms included in the list on pages p. 33-38 (entitled "Bulgarian elements in Aromanian onomastics") the author proposes as etymons words originating from Bulgarian, Serbian, Turkish, Romanian, Ukrainian, Greek, Celtic, Gothic, Arabic, Latin, Sanskrit and Aromanian, and in most cases he suggests several etymologies from different languages/dialects for the same anthroponym. Moreover, although for certain names the author specifies that the origin is unknown, he still suggests a series of terms from various languages that are similar to the names of people under analysis. Here are a few such examples: "Galiu, NN [nickname] < u.t. [uncertain etymology], Gallus, TN [toponim] Galul, Bg. Galo" (p. 36), "Mircea, MGN [male given name] < mir - Bg. мир 'peace, harmony, understanding', or 'world', mer-, Gr. popos-, Celtic maros, Gothic mar 'praise', Rom. a mări, a mărturisi or IndoEuropean mer, mor, mar 'man, young man / woman, young woman'; Mirciu, Mirela, Mirșavela” (p. 36); „Vulcănéscu, SN [surname, family name] < Vulcan + suff. -escu, Vulcan" (p. 38). Unfortunately, Dumitru Carabas neither mentions where the list of anthroponyms is selected from, nor does he state from where he selected each etymologic proposal, failing thus to apply the norms specific to onomastic research, documentation and etymology, and therefore undermining the quality of his article.

Vlad Cojocaru signs the article entitled $\mathrm{La}$ dénomination toponymique personnelle et l'evolution sociale (p. 41-49), in which he aims at analyzing the "chances" of pre-toponymic formations (namely the sentences used to identify a certain place) to turn into toponyms, based on old documents in the first volume of the collection Documenta Romanice Historica. A. Moldova. The author presents several cases of identification of a village or land according to various elements (geographical objects, landmarks, present or former owners) by analyzing the manner in which pre-toponymic forms, as well as other forms of denomination, such as collocations (of which the author restores an identification by means of a sentence), used to indicate, more or less precisely, the location. Furthermore, the author notes how the change of ownership determines the replacement of village names; for instance, when Oancea, Cîndea's son, is given "seliștea lui Drăgoi" [Drăgoi’s land], the toponym remains in that stage, according to the author. However, since there are very few written testimonies from the time, we cannot claim beyond doubt that the village was not called at a certain moment ${ }^{*}$ Oancea or ${ }^{*}$ Oncești, being subsequently disbanded or included into another village. As the author rightfully notices, a perspective upon a larger period of time would be even more interesting, as it would most likely capture more aspects of the evolution of the denominative system from its pretoponymic towards its toponymic stages. Sadly, and we do not know whose carelessness this should be blamed on, the quotations from these documents are

\footnotetext{
${ }^{4}$ Several families called Budan are still to be found today in the village of Cărpeniș.
} 
rendered in the article in French, the language the article is written in, while most of them are attached a footnote where the respective quotation is rendered (identically or quite similarly) still in French!

Silvia Pitiriciu notes that some monasteries took over the name of the place they are situated in. Starting from a list of 50 names of Romanian monasteries, the author produces a classification of these names accompanied by examples and explanations for the origin of the toponyms on which the names of those religious settlements are based (Le rôle de la toponymie dans la fixation des noms de monasteres, p. 50-59). Some of the etymologies proposed by the author are not convincing; for instance, the name of the village Brădicești, from which the homonym monastery took its name, is not derived from the common noun brad, but, as proven by documents, from the name of person Bradici (cf. Documenta Romanie Historica, A. Moldova, vol. I, p. 213).

Viorica Răileanu explains, in her study entitled Le «crépuscule » des noms de baptême. Connotations insolites, (p. 60-68), why some forenames are no longer preferred by parents. These are either very old (Badea, Bucur, Muşat, and the like) or, because of their usage in various collocations or contexts, have gained pejorative connotations (Marghioala, Tănase, Tanda and Manda, etc.). We do not know how common these collocations and the negative meanings of these forenames are (for instance, Tănase = “insensitive person", p. 62), yet we tend to believe that some of them are avoided because they have simply become obsolete, while some others are perceived rather as family names (Tänase, Stan, Chirică).

Dragoș Vlad Topală analyses the names chosen by the Ford vehicles producer for its models. The explanations provided for the names are well documented, while the chronological approach is particularly interesting.

The publication includes, as usual, a large section of lexicological studies. In the article entitled Semantic Analysis of "Black and White" Idioms in Greek, Polish, Russian and Serbian (p. 77-91), Panagiotis Asimopoulos groups, according to their connotation, various expressions or phrases from Greek, Polish, Russian, and Serbian that contain the words white and black; equivalents of many of these phrases are also to be found in Romanian (alb ca hîrtia, cap/păr alb, sportul alb, magie neagră, zile negre, negru ca noaptea, negru pe alb, etc.) and we should have found it extremely interesting if the study provided explanations for the origins of these phrases. Topics from the field of onomastics are also analyzed in the articles signed by Inga Druță and Ana-Maria Mincu (Appellativization in the Colloquial-Argotic Language, p. 118-123), who present several cases of de-onymization, as well as by Anatol Eremia (The Derivation of Proper Names: Semantic Procedures, p. $124-136^{5}$ ), who provides examples of "semantic derivation" (according to the author, this collocation refers to the process of vocabulary enrichment through the accumulation of meanings by various common or proper nouns). The articles signed by Simina Badea (The Prefix Dis- in Legal Language, p. 92-101), Alina Gioroceanu (Procedural Relationship Dynamics in Encoding Parties in a Civil Trial, p. 146-151), Manuela Lavinia Istrătoaie, Diana Dănișor (Don et donation. Considérations terminologiques et juridiques, p. 152158), Cristina Stanciu (Sur le contrat de transport routier de marchandise en trafic interne et les termes spécifiques à cette matière, p. 213-220) are included in the area of legal terminology. Nicoleta Mihai performs a very interesting study on La propagande dans le langage communiste roumain (p. 159-180), where she provides a diachronic analysis of the main features of the discourse of "Scinteia", the official publication of the Romanian Communist Party during the period when Nicolae Ceaușescu ruled the country. Ion Popescu-Sireteanu's article, Des lexemes interjectionnels dans l'usage pastoral (p. 181-206), adds to some of his previous research, among which his doctoral dissertation entitled Termeni păstorești in limba română (pe baza ALR), comprising a list of interjections (as well as words derived from them) identified in the vocabulary of shepherds; the terms were extracted from numerous studies of linguistics and folklore, dictionaries and linguistic atlases, monographs and literary works. Some analyses of semantic fields are performed by Mihaela Geană, in The Semantic Field of the Word "Man / Men" (p. 137-145) and Adela-Marinela Stancu, Le Champ sémantique du mot bleu (p. 221-230).

The section dedicated to lexicology also includes articles signed by Dana Dinu, Varro on Lexical Cre-

\footnotetext{
${ }^{5}$ The Romanian version of this article was published in "Philologia", the journal of the Academy of Science of Moldavia (no. 34/2017, p. 54-66, [online]).
} 
ation in Latin (p. 102-117), Simona Nicoleta Staicu, Medical Jargon: Collocations, Typologies, Distribution (p. 207-212), Mădălina Strechie, Military Latin and Its Impact on Mentalities (III) (p. 231-236) și Mariana Vârlan, Small vs. Capital Letter in the Writing of the Recent Noun Derivatives in the Present Journalism (p. 237-242).

As in every issue, the "Studii și cercetări de onomastică şi lexicologie" [Studies and Researches of Onomastics and Lexicology] journal includes contributions signed by young researchers in the field (Alina Dănilă, Trade Names of Pastries: Pies; Loredana-Maria Ghioală, Neological Lexis in Cartea Nunţii by G. Călinescu; Ionela Denisa Nica, Des nomes propres aux nomes d'objects; Corina-Agnana Pasăre, Des toponymes aux noms des éléments chimiques $^{6}$; Loredana-Georgiana Popescu, Xenisms of Spanish Origin in the Work Impresii asupra literaturii spaniole by G. Călinescu; Angelica Preda,
De la terminologie textile: la laine), reviews and book and symposium reviews, as well as a selection of newly issued titles.

We have accessed many of the previous volumes of this journal and we have presented them on various occasions and appreciated them for the diversity and value of the articles. Its value is beyond doubt appreciated by many others, as proven by the large number of authors that publish their articles and by the fact that it is listed in several international indexation databases and ranked B following the 2012 evaluation process carried out by CNCS. It is commendable that the journal is issued constantly (the volume issued in 2007 is its $10^{\text {th }}$ volume) and has high quality articles (we wish to believe that any "shortcoming" identified in this issue is nothing but accidental) and we are looking forward for the following volumes.

\footnotetext{
${ }^{6}$ In our opinion, the cases discussed by the author are not results of antonomasia, as stated in the article, but names chosen to honour the locality/region/country of origin of the researcher or according to the name of a place where the respective chemical elements were discovered or are to be found in great abundance.
} 